\title{
Tourism \& Covid-19 (Coronavirus Impact Inventory to Tourism Stakeholders in North Sumatera)
}

\author{
Samerdanta Sinulingga \\ Universitas Sumatera Utara, Indonesia \\ danta@usu.ac.id
}

\begin{abstract}
This research aims to map the problems posed by COVID-19 to tourism conditions in North Sumatra to near the conditions of zero tourism. To date, no effort can be made by the tourism industry to solve the problem of COVID-19, only await the government in tackling it. From The study it was found that the keys indicators in measuring the impact of COVID-19 on tourism are; The impact on economic, social, environmental also the assessment through time, change, and quality of tourism. A new finding is that the impact of tourism can also be assessed through time, change, and quality of tourism. This data is using qualitative methods through in-depth interviews with four major stakeholders of the tourism industry; management of tourist destinations, tour agencies, accommodation, and transportation services. The results of this study illustrated the chronology of tourism activities to zero tourism situation, from the four main stakeholders, which in charge of transportation services and tour agency was the most affected stakeholder and could not operate in the time of COVID-19. The results of the study can be a formula in formulating a strategic tourism management policy during the outbreak until the tourism activity can be normal again.
\end{abstract}

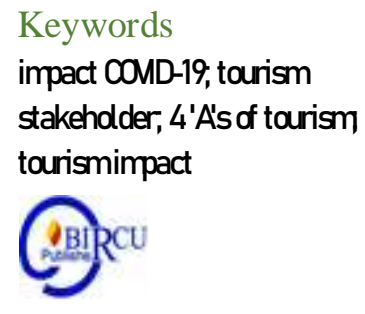

\section{Introduction}

Coronavirus or COVID-19 has a very large impact on the atmosphere of tourism globally, especially in 2020. With a very fast spread, COVID-19 can make various countries in the world self-quarantine and affect 60 million people around the world both economically, socially, and environmentally (Zandi, February 06, 2020). COVID-19 has been categorized as a pandemic, restricting the movement of people and goods, disrupting vital components of human life such as travel, trade, food supplies, financial markets (OSHA, March 13, 2020; Chinazzi et al, 2020), and worst of all, humans are not can immediately provide technical assistance without adequate equipment, unpreparedness in the distribution of aid can also have a dangerous impact (World Health Organization, February 03, 2020). Almost makes humans unable to do anything except stay at home (World Tourism Organization, March 23, 2020).

Tourism is a strong driver of economic growth and job creation (Ministry of Marine Affairs and Fisheries, December 11, 2019). With growth touching the US \$ 7 trillion figure, the tourism services sector accounts for 10.4 percent of global Gross Domestic Product (GDP), this making tourism the third largest global export sector in the world, after chemicals and fuels. The contribution of tourism to global GDP is estimated to grow by an average of 3.8 percent per year over the next 10 years. Tourism can be said to be a job-creation engine, capable of supporting 313 million people worldwide, or one in ten jobs worldwide (Ward, January 01, 2017; Perrottet, January 01, 2019). 
The various things above were then significantly corrected by the COVID-19 outbreak. Global tourism was paralyzed in the span of a few months (OECD. March 2, 2020). This incident made all tourism in Asia devastated by losing state revenues reaching \$105-115 billion (Carnell, February 24, 2020). UNWTO predicts that there will be a decrease in tourist visits by 20\% -30\% in 2020 (World Tourism Organization. March 27, 2020). If this continues, the WTTC predicts global tourism could be negatively affected by up to 25 percent by 2020 . This is equivalent to the loss of three months of global travel. This could lead to a 12-14 percent reduction in jobs (World Travel \& Tourism Council, March 13, 2020).

The impact of COVID-19 has also greatly affected the tourism sector in Indonesia (Budiyanti, 2020), especially North Sumatra Province. It was noted that foreign tourist visits to North Sumatra fell by 14.82 percent in January 2020 (Alfi, March 02, 2020), until April it almost touched zero tourism or a period of loss of tourism activity due to regional quarantine. In retrospect, there have been many attempts by the government to increase development in the tourism sector to attract tourists (Utami, 2016), especially in North Sumatra Province. North Sumatra Province itself has one of the super-priority tourism destinations for Indonesian tourism development, namely Lake Toba (Ministry of PUPR, 2019). Through the vision of Realizing the National Tourism Strategic Area of Lake Toba as a leading tourism destination,

Based on the data above, the first thing to do is to identify the problem of the impact of COVID-19 on the tourism sector in North Sumatra. This was done because of the widespread speculation / confusing information regarding the impact of COVID-19 on tourism in North Sumatra (Sudiar, March 27, 2020). This is where the urgency of this research lies because the public and other researchers want to get accurate, complete, and scientific information about it. This research will clarify the impact and problems faced by tourism stakeholders in North Sumatra. Tourism and COVID-19 information in North Sumatra are still limited to online news, newspapers, and individual opinions that need to be compiled and studied so that they can be scientifically displayed. The results of the inventory from this study can be used in the preparation of mitigation strategies and handling of tourism in North Sumatra during and after the COVID-19 issue. Errors in identifying problems will result in errors in preparing the planning scheme until later implementation (Avwontom, March 27, 2020). Matherne (2004) states 'If you fail to plan, you are planning to fail'. The purpose of this study is to inventory all the impacts and problems currently faced by all tourism stakeholders in North Sumatra.

\section{Review of Literatures}

\subsection{Tourism Impact Inventory}

The UNWTO report entitled "Impact assessment of the COVID-19 outbreak on international tourism" shows a theoretical pattern in inventorying the impact of COVID-19 on various tourism sectors (World Tourism Organization. March 27, 2020). In the UNWTO assessment or assessment technique, several measurable indicators are compiled, namely:

1. Timing of Impact Assessment: the impact of COVID-19 on tourism is measured by comparing before and after the outbreak.

2. Impact Assessment through Change: the impact of COVID-19 on tourism is measured through changes that have occurred significantly in the Tourism Industry in North Sumatra Province, which can be either negative or positive (Muresherwa, 2020). In general, the negative effects of tourism can be in the form of conflicts, shocks, decreases, weaknesses, and so on, while positive effects can be in the form of growth, opportunities, support, quality improvement, and so on. Impact assessment through change can be measured from two perspectives, namely direct or active impacts and indirect or passive impacts (Ciangă, 2017), 
and in this study, only the direct impact of COVID-19 is measured on tourism stakeholders in North Sumatra.

3. Impact Assessment through Tourism Quality: the impact of COVID-19 on tourism is measured from the impact of the 4A components, namely Tourist Attractions, Tourism Accessibility, Amenities, Ancillary Services (Cooper, 2000), in North Sumatra Province.

4. Impact Assessment through Economic, Social and Environmental: the impact of COVID19 on tourism is measured by the impact it exerts on Economic, Social and Environment (Muresherwa, 2020). In general, the scope of this study is very broad, requires large resources in its implementation, uses a large variety of methods and references because it touches various elements in the field of tourism science. UNWTO is very aware of the difficulty in measuring this element, therefore other researchers are free to take specific or general domains in their research from the three categories.

The theory above is a unity that can be explained simultaneously in certain matters because one another has a close relationship.

\subsection{Tourism Stakeholders}

Tourism is an industrial sector which is currently got a lot of attention from many countries in the world. The tourism sector is believed to have the ability to increase economic growth (Maciej Debski 2013). Moreover, the tourism sector is positively encouraged to be able to replace the oil and gas sector which has been the main capital in the country's foreign exchange earnings (Siswanto 2007). The advantage of the tourism sector lies in its ability to increase foreign exchange and to drive various other business sectors such as the home industry. Thus, developed countries and developing countries continue to develop and improve the quality of their country's tourism. (Amin et al, 2019)

Tourism is one of the determinants of national economic growth because it can influence the growth of other sectors in the economy (Gokovali \& Bahar, 2006) and also grows very fast during this decade (Dogru \& Bulut, 2018; Wu et al., 2000). Sustainable tourism development can be completed by creating opportunities through networking and cooperation with service providers, where stakeholder engagement, the development of locally oriented codes of conduct, and local government participation are crucial factors for sustainable tourism success (Welford \& Ytterhus in Nurlina, 2020).

Zehrer (2014) states that human resources in tourism can be interpreted as stakeholders or actors who carry out tourism services either actively or passively. According to Nare (2017), the stakeholders themselves are divided into two types, namely major stakeholders and minor stakeholders. Nare explained that: "... Major stakeholders have a high level of ability to influence the outcome of a decision and also have an interest in the outcome while minor stakeholders have a low ability to influence the decision. In this research, the impact to be studied comes from actors who are within the scope of the 4A component, which is the major stakeholders in Tourism Attractions, Tourism Accessibility, Amenities, Ancillary Services (Cooper, 2000). 


\section{Research Methods}

This type of research is qualitative research, using phenomenology. The research subjects in this study are major stakeholders, namely stakeholders who have direct interests in North Sumatra Province, such as Tourist Attraction service providers, Tour Agencies, Accommodations, and Tourism Transportation service providers. To provide generalizations, the key informants were the Chair of the North Sumatra Tourism Industry Association as the key informant, the Main Informant, namely the Chairperson of the Indonesian Hotel and

Restaurant Association for the North Sumatra Region, the Association of Indonesian Experiential Learning (AELI) in the North Sumatra region, the North Sumatra Nature Guide Community, the Chair of the Association of The Indonesian Tours And Travel Agencies (ASITA) North Sumatra Region. The period of the study until the last data was collected, namely data for the last 3 years (based on a question/interview scheme with informants) until April 6, 2020. The technique of collecting informants used purposive sampling and snowball sampling. There are 2 data sources in this study, namely: 1) primary data sources (interviews with informants), 2) secondary data sources (digital information/ebooks, online news sources, books). The research instrument used semi-structured interview guidelines. The observation technique uses a non-participatory observation. The data analysis technique in this study used the Miles model and 1) primary data sources (interviews with informants), 2) secondary data sources (digital information/ebooks, online news sources, books). The research instrument used semi-structured interview guidelines. The observation technique uses a non-participatory observation. The data analysis technique in this study used the Miles model and 1) primary data sources (interviews with informants), 2) secondary data sources (digital information/ebooks, online news sources, books). The research instrument used semistructured interview guidelines. The observation technique uses a non-participatory observation. The data analysis technique in this study used the Miles model and Huberman in Yusuf (2016: 407), as: reduction data, display data, withdrawal conclusion/verification.

\section{Results and Discussion}

\subsection{Impact of COVID-19 on Tourism Attraction Service Providers (DTW)}

The Association of Indonesian Experiential Learning (AELI) in the North Sumatra region, which consists of all Outbound / Outdoor service providers under the Ministry of Tourism and Creative Economy certification, stated that in a period of 3 years (2017-2019) the increase in demand for outbound tourism types in North Sumatra was very large. This request was able to touch the figure of up to $30 \%$ at the end of 2019 or 2 requests per month at each service provider, however, it was significantly corrected to Zero / Zero in March 2020 (along with government instructions circular Number: 440/2666 / 2020 regarding Increased Alertness Against the Risk of Corona Virus Disease (Covid-19) Infection in North Sumatra. Service providers estimate that losses can reach 1.2 billion Rupiah in Semester I. If in the first semester of 2020 it does not show positive changes, each service provider will lay off its workers or staff up to $50 \%$ of the 2,368 workers in Outbound / Outdoor attraction service providers, and if the impact of the outbreak continues then in semester II, an increase of $25 \%$. The service provider prepares a scenario if this issue is resolved in the first semester, what will be done is to increase the volume of positive coverage of tourism conditions on a massive scale to motivate prospective tourists to carry out outbound / outdoor tourism activities.

This also applies to all-natural, cultural, and man-made tourism service providers in North Sumatra Province, such as natural bathing tourism services, museums, zoos, fun-land, shopping centers, and historical tourism centers. The Langkat Regency Nature Tourism Guide 
stated that the movement of decreasing tourist visits due to the impact of COVID-19 began to occur in early February 2020. Where since 2017-2019, the increase in tourist visits to the Body Rafting location in Langkat Regency has grown gradually, and bathing service providers have been recorded. nature can receive visits of more than 5000 people per week which are spread out at each natural bathing location in Langkat Regency. DTW service providers earn more than 7 million rupiahs per week. For now, from March to mid-April.

This is also a concern for tourists, especially foreign tourists (especially European). Tour service providers who have good relations with foreign tourists convey that there is a tendency for extreme trauma for European tourists to return to tourist destinations in Asia. The European tourist market will likely be very unstable until the beginning of 2021. With tourism which is vulnerable to social issues, especially the issue of re-opening a market in Wuhan which continues to sell wild animals, especially bats, which are thought to be the initial source of the coronavirus disease, it has become a major aspect that influences the tourist decisions of European tourists visiting the Asian region.

From these negatives, there are also positive things that have occurred from the quarantine of this area, especially in areas with the theme of nature protected areas or protected areas such as Tangkahan and Bukit Lawang. Although the ban on crowding has been passed, the community has taken the initiative to revitalize natural conditions through the clearing of troughs and riverbanks as well as forests. Community observers of the environment around the protected area reveal that this condition opens up a huge opportunity for nature (especially the buffer zone/utilization zone) to recover.

\subsection{Impact of COVID-19 on Tour Agency}

The impact of Zero Tourism caused by COVID-19 also greatly affects sectors that sell tour packages. The first point of the tour agency problem began in early 2018 with the increase in ticket prices and additional costs for customers who have excess baggage weight. Indonesia's packaging tour economy system which always prioritizes competitive prices must be corrected significantly. The increase in airline ticket prices has resulted in changes in the price of increasingly expensive tour packages. Tour agencies have to quickly fix price rates that shock the atmosphere of tourism in Indonesia, especially domestic and inbound tour packages. Complaints from tourists cannot be avoided, especially when a price increase is not the same as an increase in services received by customers. With the increased price there is still damage to baggage, and other similar problems when the price has not changed. To maintain the previously marketed price on a large scale, Tour agencies are forced to create a strategy so as not to lose the tourism market, namely by changing the transit route. The Medan-Bali tour package, which is the main tour package, was revised, where usually Medan-Jakarta-Bali became Medan-Kuala Lumpur-Bali. This complaint continues to roll out and is discussed at the local level until the Ministry until the end of 2019 which is the beginning of the COVID19 issue to occur.

The problem regarding airplane ticket prices has not yet been resolved, the tour agency is faced with a new problem, namely COVID-19 which began to enter the Indonesian tourism system in February 2020. The tourism market continues to show negative changes and dives sharply at the end of March or early April until it finally shows zero numbers. zero.

Cancellations start from the inbound tour package, which shows a $10 \%$ decrease in early January 2020, which means that out of 10 tour groups there will be 1 group canceling the order even though an advance has been given. To control market volatility, the government then gave discounts of up to $50 \%$ for airplane tickets, however, this did not help much of the tourism market situation, instead, it generated negative sentiment and a more massive spread of fear for visitors. In February the cancellations sped towards 40\%, and at the end of March, the 
Governor's circular letter on raising awareness was issued, which became the starting point for zero tourism in North Sumatra Province.

Tour agency has a large organization, namely ASITA North Sumatra. There is 300 companies of which $40 \%$ are inbound and outbound tour players. They estimate that in the first semester, the losses suffered from COVID-19 are more than 100 million rupiahs in each service provider company or a loss of around 100 billion rupiahs from the accumulated membership above. At the end of March, all tour companies gave their workers the option to terminate their employment or be sent home without salary. Based on interviews: all workers or $100 \%$ decide to be laid off without a salary, but the next problem is the operational costs of the company's fixed costs such as electricity, water costs, especially the maintenance of tourist websites that require large costs every month.

\subsection{Impact of COVID-19 on Accommodations}

In general, accommodation in North Sumatra reap significant benefits three times a year, namely in January, February, and the fasting month. The challenge is not much different from that of tour agencies, in 2019 it was a difficult year for the hotel and restaurant sector about airplane ticket prices which can make tourists think of traveling. The price comparison between traveling within the country itself is more than double that of traveling abroad because of the impact on increasing the price of domestic air tickets.

Compared to 2019, the highest volatility in the tourism market occurred in 2018 along with the designation of the Lake Toba area as the Super-Super Priority Area of the Government of the Republic of Indonesia. The motivation for the tourism market, both domestic and inbound, shows significant changes. If an average is taken, the hotel occupancy rate in 2018 can penetrate the figure of more than $75 \%$ which exceeds the expectations of hotel and restaurant business players in North Sumatra. This occurs because of 1) the intensity of the central government which frequently visits North Sumatra Province, 2) The conduct of direct selling "Come to Toba" both at home and abroad, 3) There are hotel promo prices up to 50\% discount, which is then increasing market expectations of visiting North Sumatra.

In January 2020 the impact of COVID-19 was not too big for hotel occupancy, because North Sumatra's main tourism market share is domestic tourists, Malaysia and Singapore. For other provinces that are eyeing Chinese tourists, of course, it has a huge impact on the hotel occupancy rate. On February 1-15, hotel occupancy increased after Christmas and New Year. On that date, hotel occupancy rates were still in line with the expectations of accommodation service actors. After the 15th, the impact of COVID-19 began to affect the decline in hotel occupancy rates by $15-20 \%$ from a total of 22,039 rooms in various star hotels throughout North Sumatra. In mid-March, hotel occupancy decreased by $50 \%$ compared to early and midFebruary, up to the time of the announcement of increased awareness, the occupancy rate dropped to one digit or below $10 \%$ followed by the announcement of a Governor's circular. Until now, there are 24 hotel and restaurant businesses under the auspices of the PHRI of North Sumatra Province that has announced lockdowns or closed themselves from all tourism activities. The losses felt in the first semester from the impact of COVID-19 were able to reach more than 1 trillion rupiahs including the cancellation of MICE and other events. As of April 2020, hotel and restaurant service workers who have been dismissed touched the figure of more than $80 \%$ of $\pm 20,000$ hotel and restaurant workers in North Sumatra, some hotels still open inroom services but do not provide MICE services or other events. Until now, there are 24 hotel and restaurant businesses under the auspices of the PHRI of North Sumatra Province that has announced lockdowns or closed themselves from all tourism activities. The losses felt in the first semester from the impact of COVID-19 were able to reach more than 1 trillion rupiahs including the cancellation of MICE and other events. As of April 2020, hotel and restaurant 
service workers who have been dismissed touched the figure of more than $80 \%$ of $\pm 20,000$ hotel and restaurant workers in North Sumatra, some hotels still open in-room services but do not provide MICE services or other events. Until now, there are 24 hotel and restaurant businesses under the auspices of the PHRI of North Sumatra Province that has announced lockdowns or closed themselves from all tourism activities. The losses felt in the first semester from the impact of COVID-19 were able to reach more than 1 trillion rupiahs including the cancellation of MICE and other events. As of April 2020, hotel and restaurant service workers who have been dismissed touched the figure of more than $80 \%$ of $\pm 20,000$ hotel and restaurant workers in North Sumatra, some hotels still open in-room services but do not provide MICE services or other events. The losses felt in the first semester from the impact of COVID-19 were able to reach more than 1 trillion rupiahs including the cancellation of MICE and other events. As of April 2020, hotel and restaurant service workers who have been dismissed touched the figure of more than $80 \%$ of $\pm 20,000$ hotel and restaurant workers in North Sumatra, some hotels still open in-room services but do not provide MICE services or other events. The losses felt in the first semester from the impact of COVID-19 were able to reach more than 1 trillion rupiahs including the cancellation of MICE and other events. As of April 2020, hotel and restaurant service workers who have been dismissed touched the figure of more than $80 \%$ of $\pm 20,000$ hotel and restaurant workers in North Sumatra, some hotels still open inroom services but do not provide MICE services or other events.

\subsection{The Impact of COVID-19 on Tourism Transportation Service Providers}

There are four times in one high season period for tourist transportation services such as buses in North Sumatra Province, starting from 2017-2019 shows a stable economic movement. The high season for tour bus services is around Christmas and New Year, Eid, school holidays, and major Chinese holidays. There was a slight increase in 2018 by $10 \%$ due to the 'Come to Toba' event organized by the Ministry of Tourism through Indonesia Travel. The estimated figure that can be obtained by Tourism Transportation services is around 10-15 million per month during the high season for each tour bus unit. In general, what transport service managers usually do when conditions are stable as usual, will generally increase the number of tourist bus units, either credit or cash purchases.

The impact of COVID-19 on tourism transportation managers is very severe, worse than the reform era in 1998. The negative movement began in early February, when inbound tourism, such as Malaysia and Singapore, which are the main market shares of tourism services in North Sumatra, showed a decline of up to 20-25\%, but all of them were still covered by domestic market demand. At the beginning of March 2020 was a group the last one carried by tourist transportation services until April 2020 has touched the position of zero tourism. In early April 2020, workers who had been laid off touched the figure of $50 \%$ but still received a full salary, in some company policies some received only half the salary. For May 2020, in some company policies, there are still those who receive full or half salary but are not given holiday allowances (THR). In June if there is no change regarding COVID-19 in North Sumatra, in total workers do not receive any salary at all, and have the right to seek other work (resignation or respectful termination of employment).

The impact of COVID-19 on tourism transportation service players, especially Tour Bus providers, is very pronounced because most service actors take buses in installments or credit to leasing or banks with monthly expenses of up to 10-30 million per bus unit. It is recorded that around 30\% of transportation service players in North Sumatra have sold their tourist buses, both in-person and online. If the situation regarding COVID-19 does not end until June 2020 , it is estimated that $40-50 \%$ of transportation service actors will sell their assets to the market. 


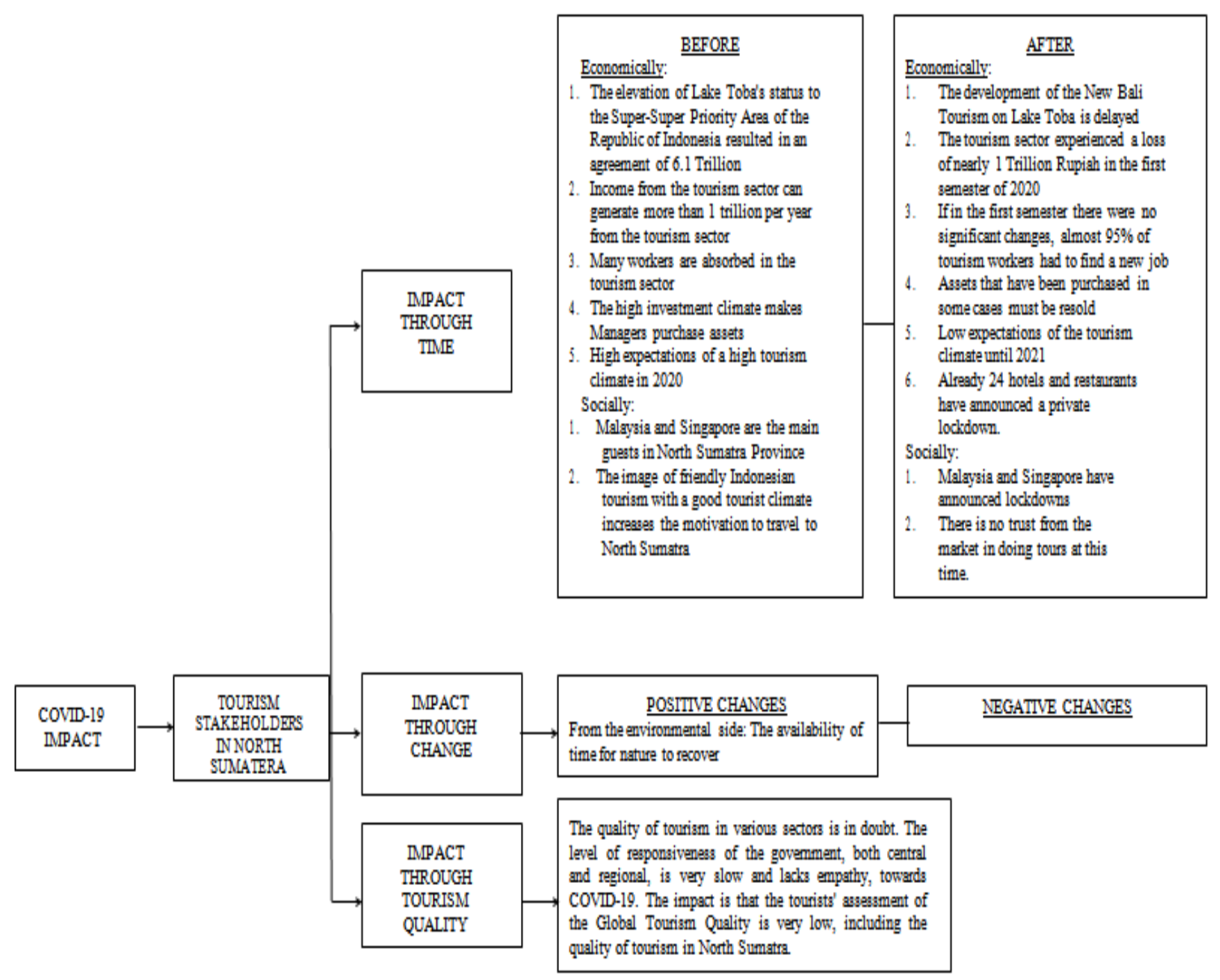

Figure 1. The pattern of the Impact of COVID-19 on Tourism Stakeholders in North Sumatra

\section{Conclusion}

Even though Chinese tourists are in the order of the third-highest tourist visit in the North Sumatra Province, they do not have a bad impact on the domestic tourism sector until March 2020 , which has a bad impact is the spread of the coronavirus which is thought to have originated in China. The negative sentiment of the tourism market cannot be avoided due to the impact of the resulting outbreak, the reason is simply that not a single tourist wants to be treated or die when they finish or while traveling in a tourist destination. Comfort and security are the most important things for tourists even though they provide a low budget when traveling. This sentiment harms all lines of tourism, including tourism stakeholders who make a living from these tourism activities.

The impact of COVID-19 is very pronounced for tourism stakeholders in North Sumatra, where this is the first time tourism has been able to touch the level of zero tourism in North Sumatra Province. Of the various tourism stakeholders, the worst hit is the tourism transportation sector, and the one that is still able to operate is the Accommodation Sector which continues to provide inpatient services even though 24 of them have announced their 
private lockdown status. UNWTO in its report entitled 'Impact Assessment of the COVID-19 Outbreak on International Tourism' provides a pattern of impacts that must be analyzed until finally there are 4 main elements in the article, namely impact assessment through time, impact assessment through change, impact assessment of tourism quality, and impact assessment through economic, social, environmental.

\section{Acknowledgment}

I would like to acknowledge the research Institute Universitas Sumatera Utara, the assistance of my staff, informant, and colleagues who help me in finishing this paper.

\section{References}

Amin, M et al. (2019). Marketing Communication Strategy To Improve Tourism Potential. Budapest International Research and Critics Institute-Journal (BIRCI-Journal). P. 160166.

Beeton, Sue. (2010). The Advance of Film Tourism. Tourism and Hospitality Planning \& Development. 7. 1-6. 10.1080/14790530903522572.

Brata, Vincent Bayu Tapa. (2007). Videografi dan sinematografi praktis. Jakarta: PT. Elex Media Komputindo.

Budiyanti, E. (2020). Dampak virus corona terhadap sektor perdagangan dan pariwisata Indonesia. Kajian Singkat Terhadap Isu Aktual dan Strategis, 12(4), 19-24.

Campbell, Eric and Lisa McGregor. (2020, Mar 31). These five strategies have helped Singapore fight off the coronavirus outbreak. Can they keep it at bay?. Retrieved Mar 31, 2020 from https://www.abc.net.au/news/2020-03-31/coronavirus-singapore-how-itfought-the-virus/12100072

Christina, Natalia, et al. (2017). Perancangan film dokumenter tentang perjalanan hidup pelaku hip-hop. Jurnal Desain Komunikasi Visual Adiwarna Vol 1 , 13-27 | vol: | issue : 2017.

Hasan, Ali. (2015). Tourism marketing. Yogyakarta: CAPS (Center of Academic Publishing Service).

Hudson, S., Ritchie, J. B. (2005). Film tourism and destination marketing: the case of captain corelli's mandolin. Journal of Vacation Marketing, Vol. 12 (3), p. 256-268.

Irawan, Etsa Indra. (2011). Sinematografi (panduan usaha mandiri). Bandung: Yrama Widya. Nurlina, (2020). Tourism Development in Langsa, Indonesia: An Overview of Tourist Attractions and Accommodation. Budapest International Research and Critics InstituteJournal (BIRCI-Journal). P.923-931

OECD. (2020). OECD interim economic assessment Coronavirus: the world economy at risk. Retrieved March 2, 2020, from https://www.oecd.org/berlin/publikationen/InterimEconomic-Assessment-2-March2020.pdf

Pemerintah Indonesia. (2009). Undang-Undang No. 10 Tahun 2009 tentang kepariwisataan. Kementerian Pariwisata dan Ekonomi Kreatif.

Pemerintah Indonesia. (2009). Undang-Undang Republik Indonesia Nomor 33 Tahun 2009 Tentang Perfilman. Presiden Republik Indonesia.

Pemerintah Indonesia. (2015). Laporan Akuntabilitas Kinerja Kementerian Pariwisata tahun 2015. Kementerian Pariwisata dan Ekonomi Kreatif.

Pemerintah Indonesia. (2017). Peraturan Menteri Dalam Negeri Republik Indonesia Nomor 3 Tahun 2017. Kementerian Dalam Negeri dan Pemerintahan Daerah. 
Polianskaia, Anna. (2017). Film tourism responses to the tourist's expectations - new challenges. SEA - Practical Application of Science Volume IV, Issue 1 (10) / 2016.

Sen, Siow Li. (2020, AUG 25). Singapore currency to stay strong until 2021 on broad USD weakness. Retrieved AUG 25, 2020 from https://www.businesstimes.com.sg/bankingfinance/singapore-currency-to-stay-strong-until-2021-on-broad-usd-weakness

Semedhi, Bambang. (2011). Sinematografi-videografi suatu pengantar. Bogor: Penerbit Ghalia Indonesia.

Sinulingga, Samerdanta \& Pardosi, Jhonson \& Bangun, Nur \& Siahaan, Hotlan. (2020). Pembuatan Film Wisata Sebagai Media Promosi Pariwisata di Desa Rumah Galuh Kabupaten Langkat. Jurnal Master Pariwisata (JUMPA). 350. 10.24843/JUMPA.2020.v06.i02.p06.

Siregar, Rizky \& Wiranegara, Hanny \& Hermantoro, Henky. (2018). Pengembangan Kawasan Pariwisata Danau Toba, Kabupaten Toba Samosir. Tataloka. 20.100. 10.14710/tataloka.20.2.100-112.

Sudiar, N. (2020). Amankah berwisata di Indonesia di tengah merebaknya virus corona? Retrieved March 2, 2020, from https://news.detik.com/kolom/d-4921691/amankahberwisata-diindonesia-di-tengah-merebaknya-virus-corona.

Suryajaya, Minghadi. (2018). Wonderful indonesia revolusi tour \& travel digital. Jakarta: Elex Media Komputindo.

Tudor, Gabriela-Cosmina. (2017). Film Tourism - A Successful Journey For New Zealand. Cactus Tourism Journal Vol. 12, Issue 2/2015, Pages 45-53, ISSN 2247-3297.

Wardani, Mentari \& Nasution, Nur. (2016). Kontribusi Pengembangan Pariwisata Danau Toba Melalui Skema Bop (Badan Otorita Pariwisata) Bagi Masyarakat Di Sekitar Danau Toba. Call for Paper FW Great Event 2016.

World Tourism Organization. (2020). Impact assessment of the Covid-19 outbreak on international tourism. Retrieved March 27, 2020, from https://www.unwto.org/sites/default/files/news/un-tourism-news-10.html

Yusuf, A. Muri. (2013). Metode Penelitian (Kuantitatif, Kualitatif, Penelitian Gabungan). Jakarta: Prenadamedia Group. 